\title{
IBA, Plant Maturity, and Regeneration of Palm Root Systems
}

\author{
Timothy K. Broschat and Henry Donselman ${ }^{1}$ \\ University of Florida, Fort Lauderdale Research and Education Center, \\ 3205 College Avenue, Fort Lauderdale, FL 33314
}

Additional index words. transplanting, growth regulators

Transplanting large field-grown palms is a very common practice in the palm-growing regions of the world, yet little is known about the factors that affect the survival of transplanted palms. Palm roots differ greatly in morphology from those of dicotyledonous trees in that all palm roots are adventitious and lack secondary thickening (Tomlinson, 1961). The regrowth response of severed roots is an important factor in determining palm transplant success (Broschat and Donselman, 1987). Broschat and Donselman (1984, 1989) have shown that root regeneration response varies considerably among palm species. Essentially all cut roots of sabal palm [Sabal palmetto (Walt.) Lodd.] die back to the trunk, but, in many other species, cut root survival is directly related to root stub length (Broschat and Donselman, 1984, 1989).

Palms in which the entire root system must be replaced following transplanting may be without any root system for up to 8 months (Broschat and Donselman, 1984). Palms with some root branching capability may have to survive with only a fraction of their original roots until new adventitious roots can be produced (Broschat and Donselman, 1984, 1989) .-A root-promoting substance that can increase the rate of root regrowth in palms, as in transplanted dicotyledonous trees (Struve and Moser, 1984; Looney and McIntosh, 1968), would be useful. We, therefore, determined if applied auxins could accelerate root regrowth in ornamental palms.

In a preliminary study, we showed that IBA, 2,4-D, and NAA, each applied at three rates, did not significantly increase root initiation in 10 species of palm seedlings. Only parlor palms (Chamaedorea elegans Mart.) produced any roots at all. These palms were physiologically more mature (i.e., had developed a trunk and were of flowering age)

Received for publication 27 Feb. 1989. Florida Agr. Expt. Sta. Journal Series no. 9758. The cost of publishing this paper was defrayed in part by the payment of page charges. Under postal regulations, this paper therefore must be hereby marked advertisement solely to indicate this fact.

'Current address: Rancho Soledad Nurseries, Inc., P.O. Box 1689, Rancho Santa Fe, CA 92067.

\section{than the other nine species.}

In a second experiment, we determined whether pygmy date "palms (Phoenix roebelenii O'Brien) and parlor palms were capable of producing a new root system following the complete removal of the existing roots. The pygmy date palms were either mature specimens having trunks 35 to $70 \mathrm{~cm}$ long or immature specimens that had not yet reached their maximum stem diameter. Mature parlor palms had at least a 2-cm long trunk, while immature specimens had not yet reached maximum stem diameter. The bases of 10 replicate palms of each species and each maturity were soaked for $5 \mathrm{~min}$ in either water (control) or $3.0 \mathrm{~g} \mathrm{IBA/liter} \mathrm{after} \mathrm{all}$ roots were cut off flush with the trunk. All leaves were cut off to reduce transpirational water loss during rooting. The palm cuttings were inserted into a container medium consisting of 4 pine bark $: 2$ sedge peat : 1 sand (by volume). Mature pygmy date palms were planted in 6-liter containers; all other palms were planted in 3-liter containers. All were placed in a shadehouse $\left(200 \mu \mathrm{mol} \cdot \mathrm{s}^{-1} \cdot \mathrm{m}^{-2}\right.$ maximum photosynthetic photon flux) and received $\approx 15 \mathrm{~mm}$ of water from overhead irrigation daily. After 10 weeks, the container medium was washed from the roots or stems, and the palms were rated on a scale of 0 to $5(0=$ no roots, $5=$ optimum rooting) for relative root mass. The containers were arranged in a randomized complete-block design and data were subjected to analysis of variance.

None of the immature pygmy date palms or parlor palms initiated roots, while rooting of older specimens having trunks was good to excellent for both species whether or not they were treated with IBA (Table 1). Rooting was confined to the basal $3 \mathrm{~cm}$ of parlor palm trunks and basal $15 \mathrm{~cm}$ of pygmy date palms. Palms of both species that rooted began producing new leaves as soon as roots were present, while palms that did not root produced no new leaves and died after $\approx 6$ or 7 months.

This study suggests that root initiation in these palms cannot be significantly improved by using IBA. However, it appears that root system regeneration in palms depends on the presence of a root initiation zone that does not form until the palm has reached its maximum stem diameter and the palm axis begins to elongate vertically. This suggestion may explain why sabal palms that have not yet developed trunks cannot be successfully transplanted, since all existing-roots in this species die after being cut and no new roots are formed in the absence of a root initiation zone. The results also suggest that the presence of a trunk and root initiation zone should enhance the transplant survival of other species of palms in which only a fraction of the existing roots survive after being severed, since these roots alone must support the palm until a trunk and root initiation zone have formed.

\section{Literature Cited}

Broschat, T.K. and H. Donselman. 1984. Root regeneration in transplanted palms. Principes 28:90-91.

Broschat, T.K. and H. Donselman. 1987. Factors affecting palm transplanting success. Proc. Fla. State Hort. Soc. 100:396-397.

Broschat, T.K. and H. Donselman. 1989. Regeneration of severed roots in Washingtonia robusta and Phoenix reclinata. Principes. (In press.)

Looney, N.E. and D.L. McIntosh. 1968. Stimulation of pear rooting by prep! ant treatment of nursery stock with indole-3-butyric acid. Proc. Amer. Soc. Hort. Sci. 92:150-154.

Struve, D.K. and B.C. Moser. 1984. Auxin effects on root regeneration of scarlet oak seedlings. J. Amer. Soc. Hort. Sci. 109:91-95.

Tomlinson, P.B. 1961. Palmae, p. 47-52. In: C.R. Metcalfe (ed.). Anatomy of the monocotyledons. vol. IL Clarendon Press, Oxford, U.K.

Table 1. Effects of IBA soaks at $3 \mathrm{~g} \cdot$ liter ${ }^{-1}$ and palm maturity on rooting of palms after 10 weeks.

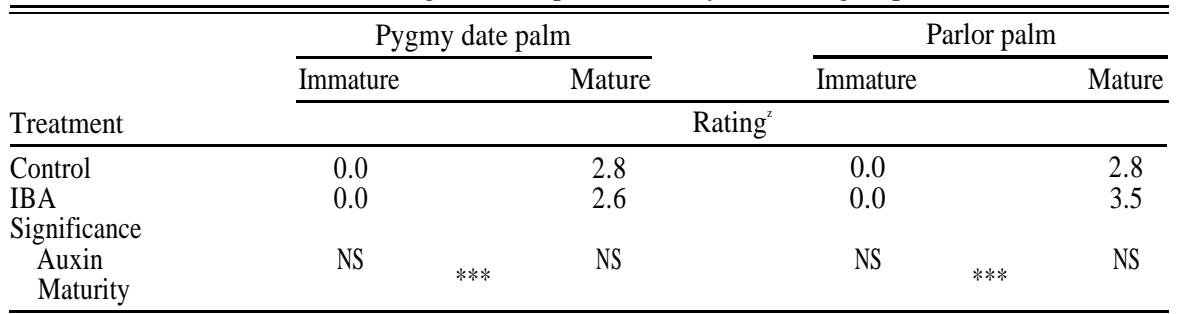

${ }_{N S}{ }^{2}$ Mean rooting scores for palms on a scale of 0 to $5(0=$ no roots, $5=$ optimum rooting).
, Nonsignificant at $P=0.05$ or significant at $P=0.001$, respectively. 